総説

\title{
希土類元素による焼結耐熱合金の 高温耐酸化性改善についで
}

\begin{abstract}
永井
忶**

Hiroshi Nagai: Improving Effect of Rare Earth Elements on the High Temperature Oxidation Resistance of Sintered Heat Resisting Alloys.

The effect of various rare earth elements added in various forms, i.e. metallic addition, dispersion of oxide and superficial application of oxide particles, on the high temperature oxidation resistance of $\mathrm{Ni}-\mathrm{Cr}$ and $\mathrm{Fe}-\mathrm{Cr}$ alloys was investigated.

Rare earth elements exhibited two excellent improving effects in reducing the oxidation rate and in suppressing the spalling of the scale. The effects of rare earth elements were much stronger than those of the other reactive elements in all additional forms.

In order to understand the mechanism by which the rare earth elements improved the oxidation resistance of the alloys, the oxygen pressure dependence of the electrical conductivity of the $\mathrm{Cr}_{2} \mathrm{O}_{3}$ doped with $\mathrm{NiO}$ and rare earths was measured. It was found that the simultaneous doping of $\mathrm{NiO}$ and rare earth elements changed the defect structure of $\mathrm{Cr}_{2} \mathrm{O}_{3}$ from p-type to n-type semiconductor at very low oxygen pressure, $\mathrm{P}_{\mathrm{O}_{2}} \simeq 10^{-9} \mathrm{~Pa}$. This result suggested that the formation of an n-type region in the scale adjacent to the alloy might act to improve the oxidation resistance by reducing the diffusion rate of cations in the scale.

(Received July 1, 1987)
\end{abstract}

\section{1 はじめに}

エネルギー効率向上の面から耐熱合金の使用温度は年 々高温化晌加ており，高温で優れた機械的性質を有 する合金の開発が盛んに行われている，高温になると酸 化や腐食速度が急激に堌大し，合金の機械的性質を著し く劣化させるので，耐熱合金の高温酸化性や耐食性が これまでにまして重要な課題になってきている．したが って，高温での䡟酸化性や耐食性を向上させる手段とし て，種々の表面処理と之もに合金自体の改善に精力的な 努力が払放れている。

耐熱合金に希土類元素を金属状で微量添加すると，高 温耐食性とくに高温酎酸化性が著しく改善されるととは 古くから知られており ${ }^{2)}$ ，多くの検討がなされてきたが， いまだ希土類元素の耐酸化性改善機構は明らかにされて いない，したがって，耐酸化性改善効果の優れている希 土類元素の種類や効果を得るに必要な添加量あるいは添 加形態についても明らかでないのが現状である。こてで は希土類元素の添加形態を金属状で添加したもの，酸化 物粒子で分散添加したむのおよび表面塗布したものに大 別して，筆者らがてれまでに得た実験結果を中心に述心 る.さらに，希土類元素の高温酎酸化性改善機構を明ら 加さするめ, $\mathrm{Cr}_{2} \mathrm{O}_{3}$ のイオン久陥構造に及ぼす希土類 元素の影響について検討した結果について白触れたい。

\section{II 金属状添加の効果}

高温耐酸化性に及活す希土類金属添加の效果を検討し

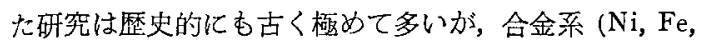

Co 基) および組成によって酸化挙動が大きく暴なるの でそれに対応して添加した希土類金属の効果にあ大きな 相違が見られる.とくに， $\mathrm{Cr}_{2} \mathrm{O}_{3}$ 保護皮膜を形成する合 金亡 $\mathrm{Al}_{2} \mathrm{O}_{3}$ 保護皮膜を形成する場合とで希土類金属の効 果に顕著な差が見られる.本稿では，紙数に制限がある ので, $\mathrm{Cr}_{2} \mathrm{O}_{3}$ 保護皮膜を形成する合金系について述べる.

一例として, Fig. 1 亿種々の活性金属を添加した Ni$20 \mathrm{Cr}$ 合金の大気中， $1273 \mathrm{~K}$ に捛ける酸化增量および 皮膜剝離量を示す3．図より明らかな上うに，希土類金 属の添加によって, 酸化速度の低減之皮膜剝離量の減少 の 2 つの効果が得られ，希土類金属の效果が他の活性金 属上りすぐれている．附熱合金を実際に使用する場合に は, 加熱, 冷却が繰り返され，そのたびに皮膜が剝離し て保護性を失うことが多いので，希土類金属添加による 皮膜剝離㧕制効果は，酸化速度の低减効果任劣らず重要 である.

希土類元素添加による酸化速度の低減および皮膜㔀離 抑制機構には，下記のような説が提唱されている.

(1) 酸化速度低減機構

（a）合金-皮膜界面での昖散障壁層の形成 ${ }^{4 \sim 87}$

(b) 保護皮膜形成元素の合金内㹡散促進9?

(c) $\mathrm{Cr}_{2} \mathrm{O}_{3}$ の核形成点としての作用 ${ }^{10,111}$

(d) 皮膜中での拡散イオン種の変化 ${ }^{12 \sim 16)}$

* 第25回 (昭和61年度) 研究功績賞受賞, 昭和62年 6 月本協 会春季大会飞て発表, 昭和62年 7 月 1 日受理。

** 大阪大学工学部金属材料工学科, $\bar{T} 565$ 吹田市山田丘2-1. 

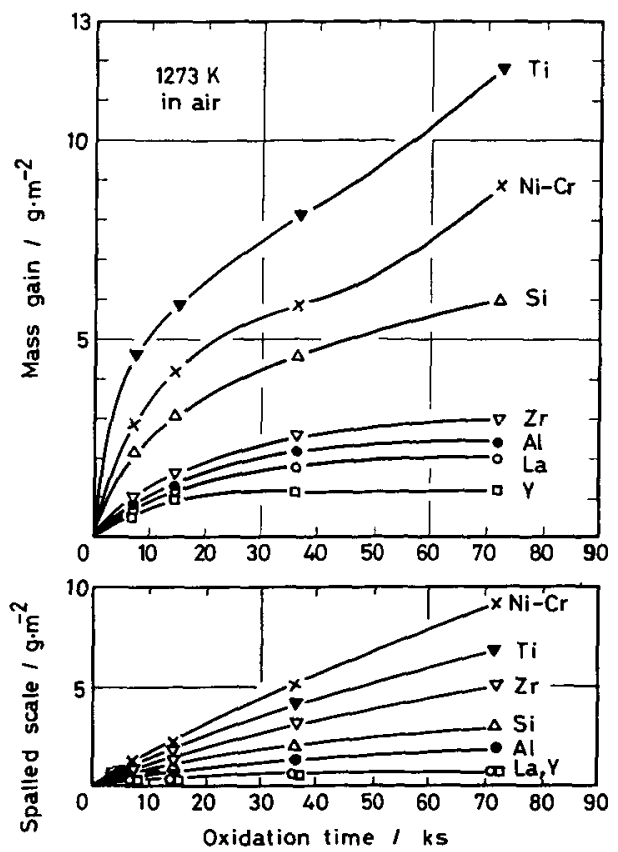

Fig. 1 Isothermal oxidation of $\mathrm{Ni}-20 \mathrm{Cr}$ alloys with various alloying elements in air at $1273 \mathrm{~K}$.

(2)皮膜の剝離抑制機構

(e) 株どめ (keying) 効果 ${ }^{17 ~ 203}$

(f) 空孔消滅点 (vacancy sink) の形成 ${ }^{21,22)}$

（g）皮膜形成反応位置の変化 ${ }^{13+14)}$

このように, 希土類元素の高温耐酸化性改善機構は多 岐にわたっており，いまだ結論は出ていない，希土類元 素を金属状で添加した場合, 希土類金属汃極めて活性で あるため，合金一皮膜界面に緻密な内部酸化層を形成し， 搪散障壁 (機構 (a)) および楔どめ効果 (機構 (e))によっ て而酸化性を改善寸るという説が多く提唱されているが， 㹡散速度の速い $\mathrm{Al}$ や $\mathrm{Si}$ の方がより緻密で入り組んだ 内部酸化層を形成するに古拘らず，それらの効果は希土 類金属より劣るなど，乙の機構のみでは説明し得ない。 金属状で添加した場合には，酸化反応のみならず合金元 素との反応む並行して起てり解积を複雑にしている上考 えられるので，系を単純化して解析を容易にするため， 希土類元素を酸化物の形態で添加し，その効果を比較し た.

\section{III 希土類酸化物分散添加の効果}

希土類酸化物粒子を分散添加した場合には，前述の金 属状添加の場合のように反応や拡散が起こらず，付随的 な現象を余りともなわないので，希土類元素の耐酸化性 改善機構を解明していく上で有効である. 筆者らは, 耐 酸化性の優れた酸化物分散強化型合金を開発するための 基礎的な知見を得るととおよび希土類元素の耐酸化性改 善機構を解明するととを目的として $\mathrm{Fe}-20 \mathrm{Cr}^{23}, \mathrm{Ni}$ -
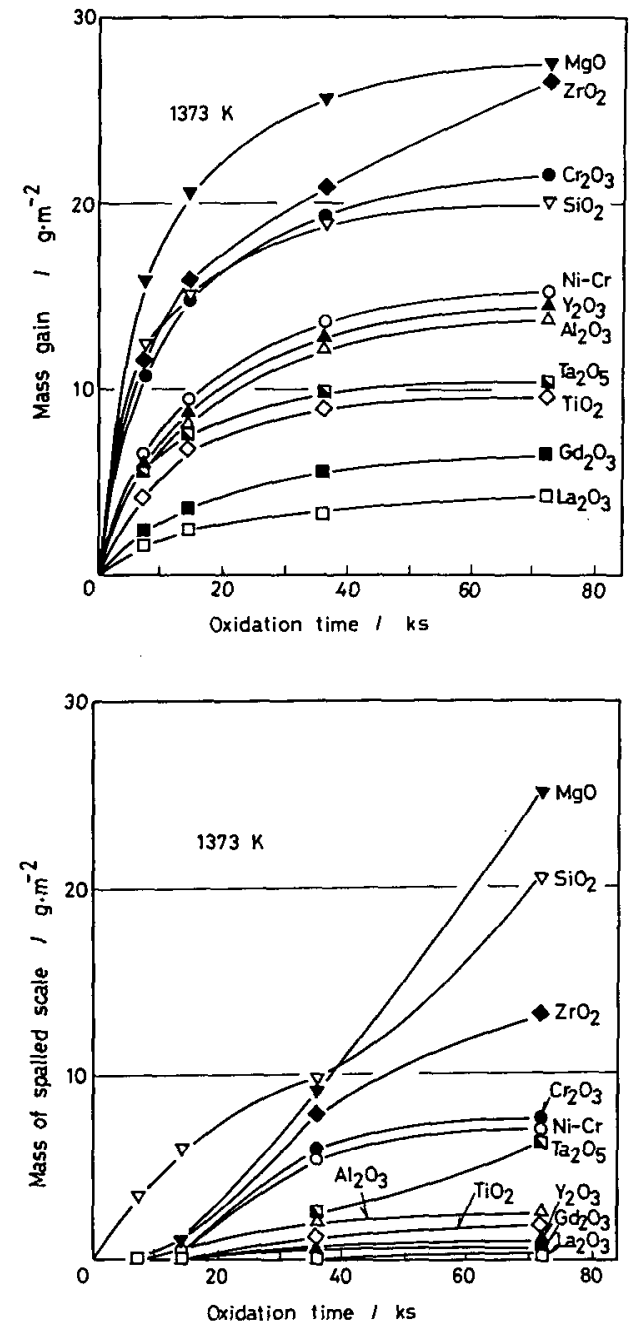

Fig. 2 (a) (b) Isothermal oxidation of $\mathrm{Ni}-20 \mathrm{Cr}$ alloys with various dispersed oxides in air at $1373 \mathrm{~K}$.

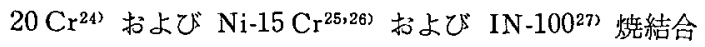
金の耐酸化性に及ほすす各種活性金属酸化物および希土類 酸化物粒子分散添加の効果について検討した。

一例として, Fig.2(a), (b) に希土類酸化物方よび種々 の活性金属酸化物粒子を分散添加した $\mathrm{Ni}-20 \mathrm{Cr}$ 蛙結合 金の大気中， $1373 \mathrm{~K}$ におりる酸化挙動定す ${ }^{24)}$. 希土 類酸化物を添加した場合，酸化物粒子が合金一皮膜界 面に凝集している様子は全く見られないにあ拘らず， Fig. 2 に見られるように, 酸化速度の低減之皮膜の剥離 抑制という2つの効果が得られ，その効果は金属状添加 の効果よりむしろ大である、さらに，興味ある結果は， Fig. 2 亿見られるように, $\mathrm{MgO}, \mathrm{ZrO}_{2}, \mathrm{Cr}_{2} \mathrm{O}_{3}, \mathrm{SiO}_{2}$ な どの添加によって酸化速度および皮膜剔離量が增大する よいう結果で，乙れは実用上重要であるばかりでなく， 前述の耐酸化珄改善機構(1)の (a)-(c) および(2)の (e)-(f) 以外の泉のが主な改善機構であるととを示している.す 

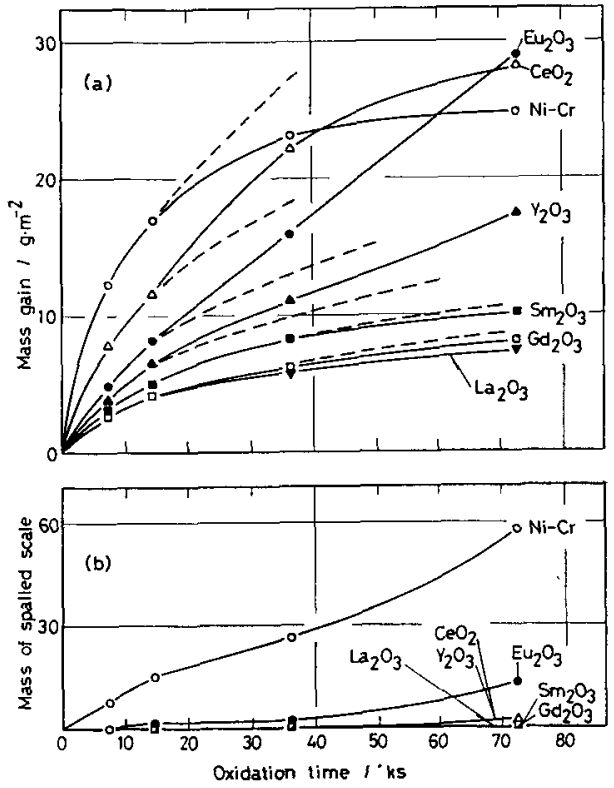

Fig. 3 Isothermal oxidation of $\mathrm{Ni}-15 \mathrm{Cr}$ alloys with dispersion of various oxides as a function of oxidation time in air at $1473 \mathrm{~K}$.

なわち，希土類元素が $\mathrm{Cr}_{2} \mathrm{O}_{3}$ 皮膜中に固溶あるいは混 入して, $\mathrm{Cr}_{2} \mathrm{O}_{3}$ のイオン久陷構造を変化させる結果，皮 膜中での昖散イオン種が金属イオンから酸素イオンに变 化し，皮膜形成反応加皮膜表面加合金一皮膜界面八变 化するという機構 (d), (g) が有力であることを示唆して いる。

希土類元秋は互いによく似た性質を有して扔り，しか あ種々の性質が原子番号の順に連続して変化している.

(イオン半径, 電子数など) したがって，希土類元素の どの性犋が耐酸化性に影響を及心゙すかを明確にするため， 希土類酸化物の種類を变えて分散添加の效果を比較した。 Fig. 3(a)(b) 飞，種々の希土類酸化物を分散添加した Ni$15 \mathrm{Cr}$ 焼結合金の大気中, $1473 \mathrm{~K}$ におりる酸化挙動を示 す. また, Fig. 4(a)，(b) に $1473 \mathrm{~K}, 20 \mathrm{~h}$ 酸化後の酸化 增量市よび皮膜豩離量を原子番号の順にプロットした。 図より明らかなように，期待に反して，原子番号の順に 対匛するような変化は見られなかったが，希土類酸化物 の種類によって効果が著しく異なるてとが明らかとなっ た. すなわち $\mathrm{La}_{2} \mathrm{O}_{3}, \mathrm{Gd}_{2} \mathrm{O}_{3}, \mathrm{Sm}_{2} \mathrm{O}_{3}$ 添加の效果は, 酸 化速度の低隇および皮膜の剥離抑制に極めて有効である のに対して， $\mathrm{CeO}_{2}, \mathrm{Eu}_{2} \mathrm{O}_{3}$ は皮膜の䟝離孛抑制する効 果は有するが，酸化速度にはむしろ有害であるととが明 らかとなった。

分散酸化物の耐酸化性改善効果は，従来主に酸化物粒. 子の添加によって合金の結晶垃が微細になり，その結果 增大した結晶粒界や試料表面に顔を出した分散粒子が酸 化皮膜形成の核टなり保護性の高い皮膜 $\left(\mathrm{Cr}_{2} \mathrm{O}_{3}, \mathrm{Al}_{2} \mathrm{O}_{3}\right)$

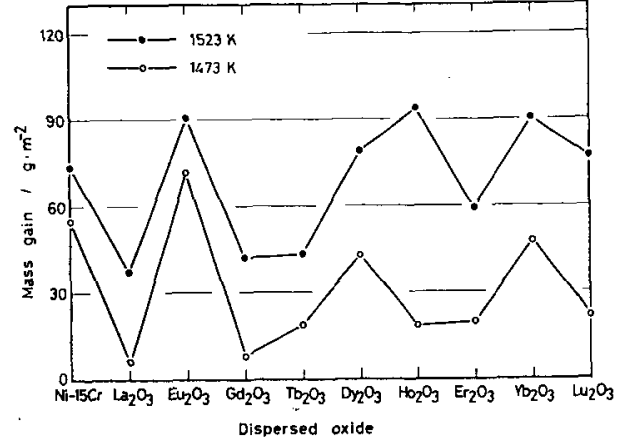

Fig. 4(a) Mass gain of $\mathrm{Ni}-15 \mathrm{Cr}$ alloys with various rare earth oxides after $72 \mathrm{ks}$ oxidation in air at 1473 and $1523 \mathrm{~K}$.

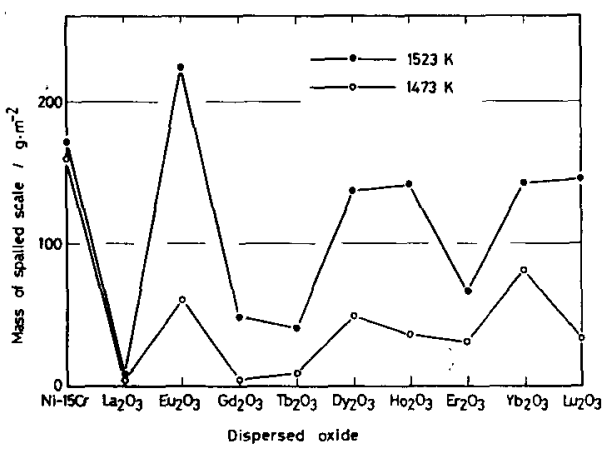

Fig. 4(b) Mass of spalled scale of $\mathrm{Ni}-15 \mathrm{Cr}$ alloys with various rare earth oxides after $72 \mathrm{ks}$ oxidation in air at 1473 and $1523 \mathrm{~K}$.

が早期に形成されるため，酸化速度が低減するという機 構 (c)で説明されてきた. また，皮膜の密着性の改善に は分散酸化物粒子が空孔消隇点として作用し皮膜剝離の 原因となるボイドの形成を抑制するという機構 (f) で説 明されてきた。しかしながら，ての機構では，上記の酸 化物の種類による酸化速度の大きな差を説明し得ない。 とくに，耐酸化性を劣化させる現象を全く説明し得ない. 上記の結果より，希土類元素は，合金の性質ではなく， 皮膜酸化物の性質を変えるととによって，耐酸化性を改 善すると考えられるが，酸化物粒子を分散添加した場合 にも，酸化物粒子之合金との反応等酸化物粒子が合金の 性質を变化させる可能性がある．したがって，次に合金 の酸化挙動に及涩す酸化物粒子表面至布の影響について 検討した。

\section{N 酸化物粒子表面症布の影響}

希土類酸化物が $\mathrm{Cr}_{2} \mathrm{O}_{3}$ 皮膜中に固溶古るいは混入す ることによって，酎酸化性が改善するという機構であれ ば，合金試料表面に希土類酸化物粒子を塗布した場合に あ，その効果が期待されるはずである。

Fig. 5 亿各種希土類酸化物を表面塗布した $\mathrm{Fe}-20 \mathrm{Cr}$ 焼結合金の大気中， $1373 \mathrm{~K}, 20 \mathrm{~h}$ 酸化後の酸化增量学単 位面皘当たりの酸化物粒子塗布量に対してプロットし 


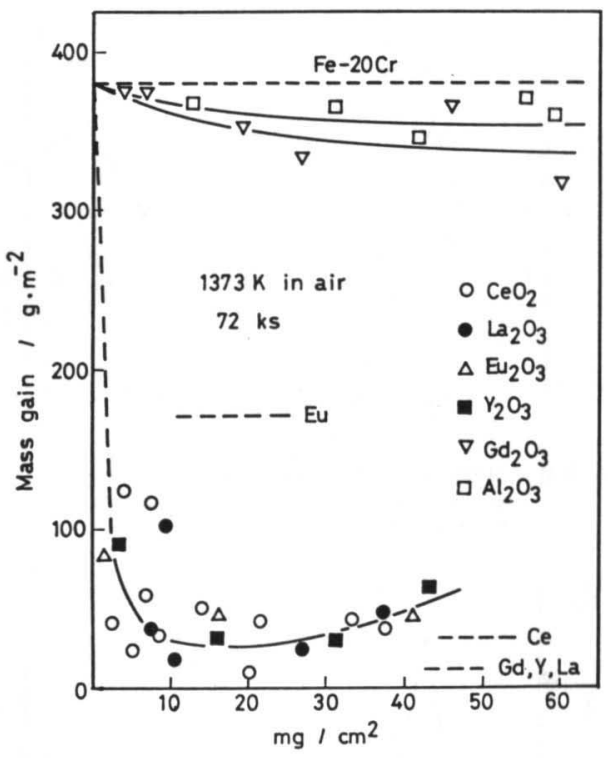

Fig. 5 Mass gain after $72 \mathrm{ks}$ oxidation of $\mathrm{Fe}-20 \mathrm{Cr}$ sintered alloys with superficial application of various rare earth oxides in air at $1373 \mathrm{~K}$.

た ${ }^{28)}$. 図中の破線は，それぞれ各希土類酸化物粒子を分 散添加した $\mathrm{Fe}-20 \mathrm{C}$ 焼結合金の大気中, $1373 \mathrm{~K}, 20 \mathrm{~h}$ 酸化後の酸化增量を示したあのである. 比較のために $\mathrm{Al}_{2} \mathrm{O}_{3}$ 粒子を表面狳布した場合の結果も示した. 表面叙 布試料は, 各種酸化物粒子をアセトン中に懸濁しその中 に無添加の $\mathrm{Fe}-20 \mathrm{Cr}$ 燒結合金試料を浸漬したのち，空 気中で乾燥させたもので, 乾燥後そのまま酸化実験に供 した. 酸化物粒子は, Photo. 1 に見られるように, 試料 表面に疎らに軽く乗っている状態にあるので, 実験結果 にバラッキが見られるが, $\mathrm{Gd}_{2} \mathrm{O}_{3}$ 以外の希土類酸化物粒

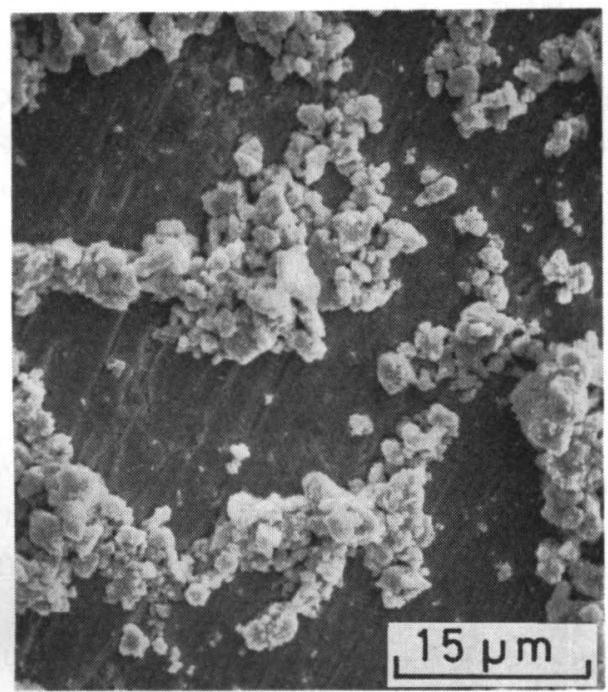

Photo. 1 SEM photograph of the surface of $\mathrm{CeO}_{2}$-applied $\mathrm{Fe}-20 \mathrm{Cr}$ sintered alloy before oxidation.
子の表面塗布によって, 酸化増量は著しく低下するとと がわかる.とくに， $\mathrm{Eu}_{2} \mathrm{O}_{3}, \mathrm{CeO}_{2}$ の場合には表面塗布し た方が, 分散添加した場合よりも優れた効果を示した. $\mathrm{Gd}_{2} \mathrm{O}_{3}$ は分散添加した場合には, 優れた耐酸化性改善効 果を示したが, 表面塗布した場合には, $\mathrm{Al}_{2} \mathrm{O}_{3}$ の表面塗 布と同様ほとんど効果を示さなかった。

酸化した表面塗布試料の断面を EPMA で観察する と, 塗布粒子のほとんどは, 酸化皮膜の外側に見られ， 皮膜内に顕著に取り込まれた様子や合金一皮膜界面に凝 集している様子は全く見られなかった，しかしながら， 効果のあった $\mathrm{La}_{2} \mathrm{O}_{3} や \mathrm{CeO}_{2}$ 塗布試料の場合には, 主 に $\mathrm{Cr}_{2} \mathrm{O}_{3}$ 酸化皮膜が安定に保持されているのに対して, 効果のなかった $\mathrm{Gd}_{2} \mathrm{O}_{3}$ 塗布試料の場合には, $\mathrm{Cr}_{2} \mathrm{O}_{3}$ の 外側に $\mathrm{Fe}_{2} \mathrm{O}_{3}$ 皮膜が厚く成長しており, $\mathrm{Cr}_{2} \mathrm{O}_{3}$ 皮膜を 通しての $\mathrm{Fe}$ イオンの外向拡散が急速に起とっていると とを示している. また, $\mathrm{Eu}_{2} \mathrm{O}_{3}$ や $\mathrm{CeO}_{2}$ は分散添加し た場合よりも，表面塗布した場合に優れた効果を示すと いう結果は, これらの希土類酸化物の価数が変化し易い ととを考虑すると，希土類元素が皮膜中に固溶あるいは 混入するととによって, 皮膜酸化物の性質を変化させて, 耐酸化性の改善に寄与しているととを暗示している.

酸化物の種類による酸化速度および皮膜剝離抑制効果 の大きな差を説明するには，合金に分散添加した酸化物 粒子が皮膜中に固溶あるいは混入して皮膜酸化物のイオ ン欠陥構造等の物性を大きく変化させる結果, 皮膜中で

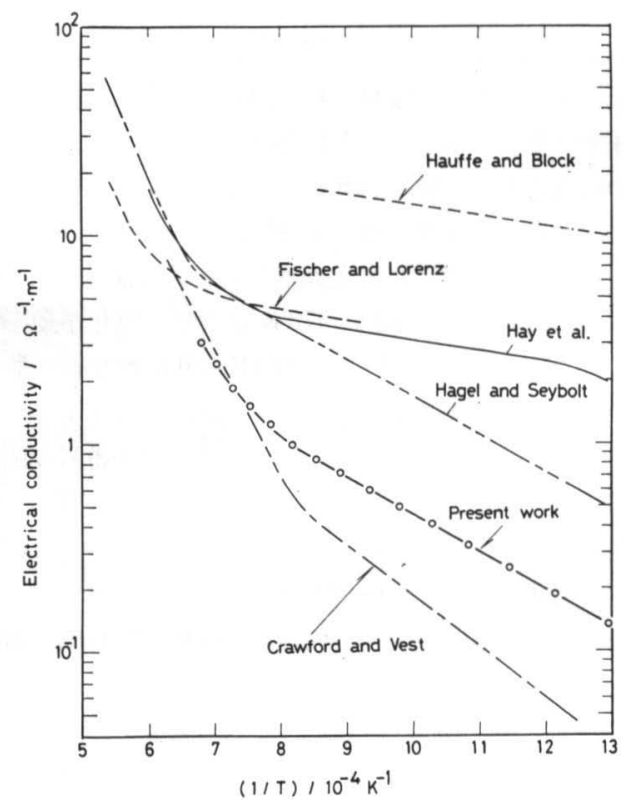

Fig. 6 Electrical conductivity of $\mathrm{Cr}_{2} \mathrm{O}_{3}$ as a function of the reciprocal absolute temperature. Results by Hauffe and Block (30), Fischer and Lorenz (31), Hay et al. (32), Hagel and Seybolt (33), and Crawford and Vest (34) are also included. 
の拡散イオン種が金属イオンの外向抎散から酸素イオン の内向拡散へ变化して，皮膜形成反応位置が皮膜表面加 ら合金一皮膜界面へ変化するという機構 (d) および（g) が有力である.しかしながら，希土類元素の固溶あるい は湿入によって皮膜酸化物のイオン久宿構造等の物性が 变化したてとを実測した報告はいまだない。したがって， 著者らは, $\mathrm{Cr}_{2} \mathrm{O}_{3}$ のイオン欠陷構造に及ほすす添加元素の 影響を明確にするため，各種元素を添加した $\mathrm{Cr}_{2} \mathrm{O}_{3}$ の 電気伝導度を温度および酸素分圧を変化させて測定した。

\section{$\mathrm{V} \quad \mathrm{Cr}_{2} \mathrm{O}_{3}$ の電気伝導度に及ぼす希土類元素の影響}

上述の上うに，希土類元素の耐酸化性改善機構として 希土類元素が $\mathrm{Cr}_{2} \mathrm{O}_{3}$ 皮膜のイオン欠宿構造を変化させ
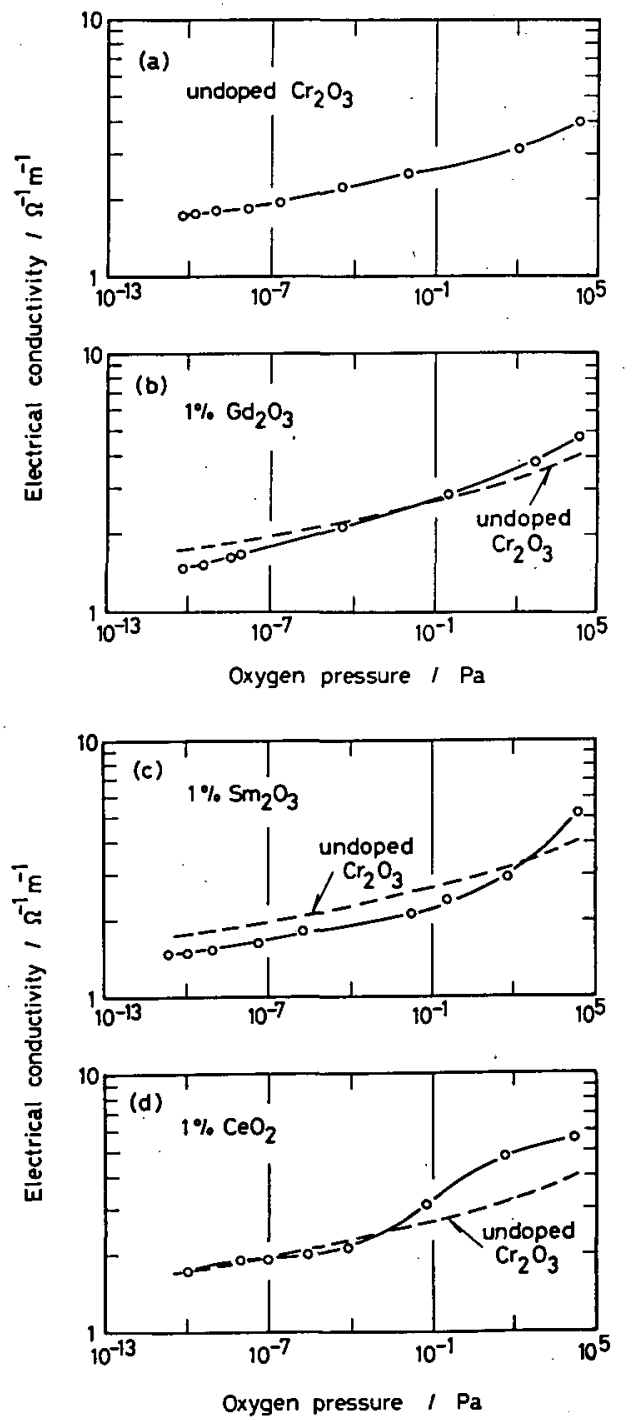

Fig. 7 (a) (b) (c) (d) Oxygen pressure dependence of the electrical conductivity of (a) undoped, (b) doped with $196 \mathrm{Gd}_{2} \mathrm{O}_{3}$, (c) doped with $196 \mathrm{Sm}_{2} \mathrm{O}_{3}$ and (d) doped with $1,6 \mathrm{CeO}_{2}$.
るという説が有力であるととをのべたが, $\mathrm{Cr}_{2} \mathrm{O}_{3}$ の欠陥 構造に及は方希土類元素の影響を検討した結果は全くな く，無添加の $\mathrm{Cr}_{2} \mathrm{O}_{3} \cdot$ のイオン久陥構造む未だ明らかで はない:

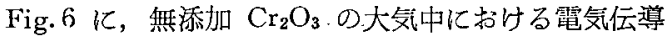
度の温度依存性を示す ${ }^{29 \sim 34)}$. 図より明.らかなように， $1473 \mathrm{~K}$ 以上の高温域のデータは比較的一致しているが, 低温域の值には大きな差異がみられる，高温域での電気 伝導度は固有 (intrinsic)なむのであり，低温域での電気

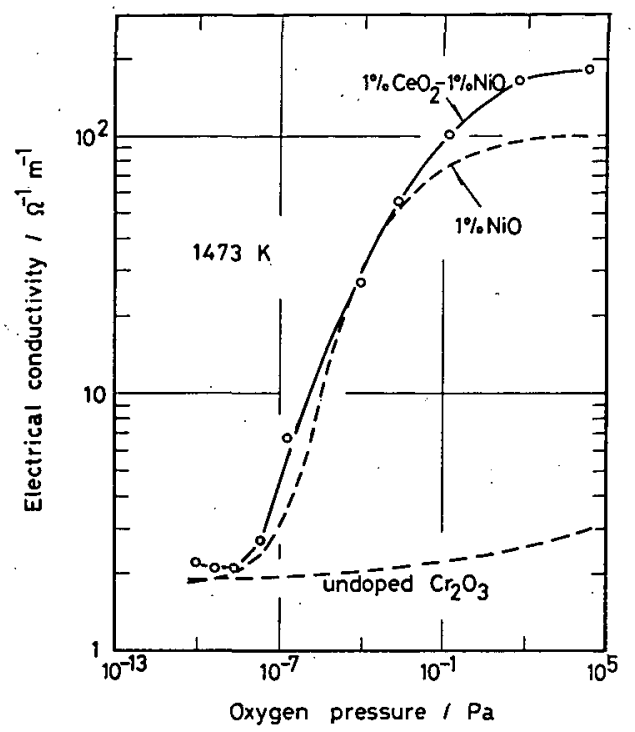

Fig. 8(a) Oxygen pressure dependence of the electrical conductivity of $\mathrm{Cr}_{2} \mathrm{O}_{3}$ doped with $1 \% \mathrm{CeO}_{2}$ and $1 \% \mathrm{NiO}$ at $1473 \mathrm{~K}$

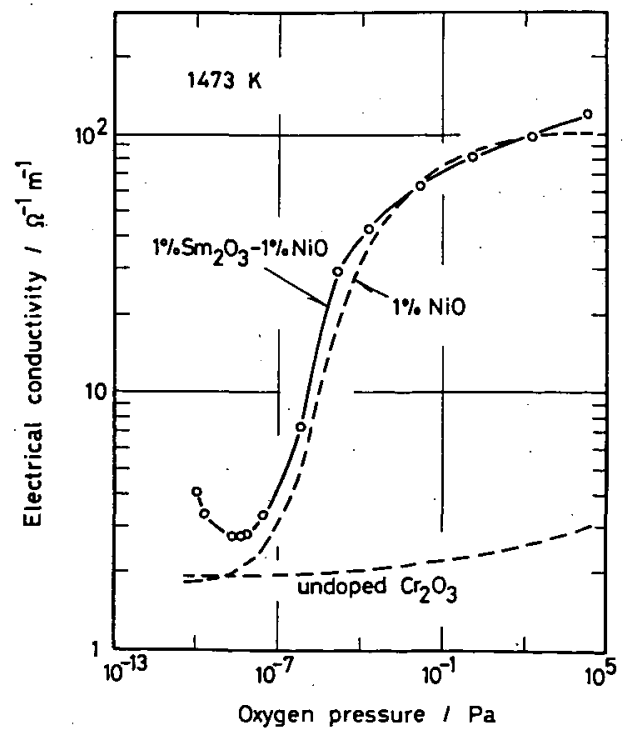

Fig. 8(b) Oxygen pressure dependence of the electrical conductivity of $\mathrm{Cr}_{2} \mathrm{O}_{3}$ doped with $1 \% 6 \mathrm{Sm}_{2} \mathrm{O}_{3}$ and $196 \mathrm{NiO}$ at $1473 \mathrm{~K}$. 
伝導度には，微量の不純物が影響していると考えられて いる ${ }^{35)}$ ：低温域での測定值の大きな差は，測定者でとで 用いた $\mathrm{Cr}_{2} \mathrm{O}_{3}$ の純度の相違によるるのと考えられる。 Fig. 7(a)(b)(c)(d) 飞無添加 $\mathrm{Cr}_{2} \mathrm{O}_{3}$ および $\mathrm{Sm}_{2} \mathrm{O}_{3}, \mathrm{Gd}_{2} \mathrm{O}_{3}$, $\mathrm{CeO}_{2}$ を $1 \%$ 添加した $\mathrm{Cr}_{2} \mathrm{O}_{3}$ の電気伝導度の酸菜分压依 存性を示す ${ }^{36}$. 高酸素分圧側で若干の差異は見られるが， いずれも酸素分圧の減少にともなって，電気伝導度が単 調に減少しており，p-型半導体特性を示している．予想 に反して，希土類元菜の添加によって $\mathrm{Cr}_{2} \mathrm{O}_{3}$ のイオン 欠宿構造が $\mathrm{p}$-型加ら $\mathrm{n}$-型へ変化していない．しかしな がら，無添加および希土類元素を添加した $\mathrm{Ni}-\mathrm{Cr} や \mathrm{Fe}$ $\mathrm{Cr}$ 合金の酸化初期に形成した $\mathrm{Cr}_{2} \mathrm{O}_{3}$ 皮膜索 IMA $に$ よって分析した結果，皮膜は純粋な $\mathrm{Cr}_{2} \mathrm{O}_{3}$ ではなく， 微量の希土類元素および $\mathrm{NiO}$ あるいは $\mathrm{Fe}_{2} \mathrm{O}_{3}$ を含有 しているてとが，明らかとなった，したがって，次に $\mathrm{NiO}$ あるいは $\mathrm{Fe}_{2} \mathrm{O}_{3}$ と希土類元素が共存した場合につ いて検討した。

一例として，Fig. 8(a)(b) $/ \mathrm{Cr}_{2} \mathrm{O}_{3}-1 \% \mathrm{NiO}-1 \% \mathrm{R}_{2} \mathrm{O}_{3}$ (R: $\mathrm{Sm}, \mathrm{Ce})$ の電気伝導度の酸素分生依存性を示す ${ }^{311}$. 図より明らかなように，先に示した $\mathrm{Ni}-15 \mathrm{Cr}$ 蝰結合金 で耐酸化性改善効果の磷れていた $\mathrm{Sm}_{2} \mathrm{O}_{3}, \mathrm{Gd}_{2} \mathrm{O}_{3}$ 之, 逆に劣化させた $\mathrm{CeO}_{2}$ とでは，低酸素圧において差異が みられる．すなわち， $\mathrm{Sm}_{2} \mathrm{O}_{3}, \mathrm{Gd}_{2} \mathrm{O}_{3}$ を添加した場合に は，低酸甞圧下で $\mathrm{p}$ 型 $\rightarrow \mathrm{n}$ 型への変化が見られるのに 対して, $\mathrm{CeO}_{2}$ 添加の場合には $\mathrm{p}$ 型 $\rightarrow \mathrm{n}$ 型への変化が 見られない。

EPMA 分析，X線回折，磁気測定の結果，ほとんよ゙ の希土類酸化物はそのままの状態で存在し， $\mathrm{NiO}$ は高酸 素圧下では固溶しているが，低酸续圧下では還元されて $\mathrm{Ni}$ 粒子として $\mathrm{Cr}_{2} \mathrm{O}_{3}$ 中に分散している. 酸化物中に 金属粒子や母相之異なる電荷数を持つ酸化物粒子が分散 している場合，母相酸化物の電気伝導度やイオン欠陥構 造およびイオン昖散速度が変化する (charged particle theory $)^{37}$. $\mathrm{p}$-型の $\mathrm{Cr}_{2} \mathrm{O}_{3}$ 中に, $\mathrm{Ni}$ 粒子抢よび酸素との 親和力の強い希土類酸化物が分散している場合，母相の $\mathrm{n}$-型導電性が增大することが考えられるので， $\mathrm{CeO}_{2}$ よ り酸素との親和力の強い $\mathrm{Sm}_{2} \mathrm{O}_{3}, \mathrm{Gd}_{2} \mathrm{O}_{3}$ 添加の場合に, n-型に変化したことが考えられる．とのことは，酸化皮

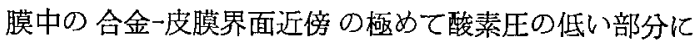
n-型の欠陥構造を有する領域が形成される可能性を示し て拉り，その領域の存在が耐酸化性の改善に寄与するす のと考えられる. しかしながら，無添加の $\mathrm{Cr}_{2} \mathrm{O}_{3}$ の久 陷構造も未だ明らかでないので,さらにデータの蓄皘が 必要である。

\section{V おわりに}

希土類元素は，金属状て添加した場合にも，酸化物粒 子を分散添加および表面塗布した場合にも，他の活性金 属やそれらの酸化物よりも，はるかに優れた耐酸化性改
善効果定示し，耐熱合金の酸化速度の低減效果之酸化皮 膜の密着性を著しく向上させる，2つの効果があること を示した。

これらの結果より，希土類元素の耐酸化性改善機構は 合金の性質を変化させることによるのではなく，皮膜酸 化物の性質を変化させることによるものであることが， 明らかとなった。

希土類元素によって皮膜酸化物の性質がごのように変 化するかを明らかにするため, $\mathrm{Cr}_{2} \mathrm{O}_{3}$ 焼結体の電気伝導

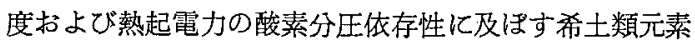
添加の影響を検討した結果, $\mathrm{p}$-型半導体特性を示す $\mathrm{Cr}_{2} \mathrm{O}_{3}$ に希土類酸化物のみ添加した場合には，殆ど変化 が見られなかったが，希土類酸化物と $\mathrm{NiO}$ とを同時添 加した場合には $10^{-9} \mathrm{~Pa}$ 以下の低酸素圧下で $\mathrm{n}$-型に変 化することが明らかとなった。このととは $\mathrm{Cr}_{2} \mathrm{O}_{3}$ 皮膜 内の 合金-皮膜界面に近い酸素ポテンシャルが極めて低 い部分に，n-型のイオン欠陷構造を有する領域が形成 し，それが金属イオンの外问拡散を抑制し，酸化速度お よび皮膜の剥離を㧕制するものと考えられる．しかしな がら，種々の現象を定量的に説明するには，いまだデー 夕あ充分ではないので，さらに詳細なデータの蓄積が必 要と考える.

\section{文献}

1）吉葉，宮川，坂木，藤代：鉄と鋼，68 (1982), 120 .

2) L. B. Pfeil: U.K. Patent, No. 459848, (1937).

3) H. Nagai, M. Okabayashi and H. Mitani: Trans. JIM, 21 (1980), 341.

4) 中山, 富士川 : 日本金属学会誌, 29 (1965), 990.

5）梁瀬，遅沢，根本：日本金属学会誌，33 (1969)，46.

6) F. H. Stott and G. C. Wood: Corros. Sci., 11 (1971), 799.

7) C. G. Giggins and F.S. Pettit: J. Electrochem. Soc., 118 (1971), 1782.

8) I. A. Kvernes and P. Kofstad: Met. Trans., 3 (1972), 1511.

9) I. A. Kvernes: Oxid. Met., 6 (1973), 45.

10) M. J. Fleetwood: J. Inst. Met., 94 (1966), 218.

11) C. S. Giggins and F.S. Pettit: Trans. AIME., 245 (1969), 2509.

12) J. Stringer, B. A. Wilcox and R. I. Jaffee: Oxid. Met., 5 (1972), 11

13) C. S. Giggins and F. S. Pettit: Met. Trans., 2 (1971), 1071.

14) H. T. Michels: Met. Trans., 7A (1976), 379.

15) F. A. Golightly, F. H. Stott and G. C. Wood: Oxid. Met., 10 (1976), 163.

16) J. Stringer and I. G. Wright: Oxid. Met., 5 (1972), 59.

17) 天野，矢島，斎藤：日本金属学会誌，41 (1977), 1074.

18) J. K. Tien and F. S. Pettit: Met. Trans., 3 (1972), 1582.

19) C. S. Giggins, B. H. Kear, F. S. Pettit and J. K. Tien: Met. Trans., 5 (1974), 1685.

20) I A. Allam, D. P. Whittle and J. Stringer: Oxid. Met., 13 (1978), 38.

21) A. Tsuji: Met. Trans., 11A (1980), 1965.

22) J. Stringer, A. Z. Hed, G. R. Wallwork and B. A. Wilcox: Corros. Sci., 12 (1972), 625. 
23) H. Nagai, Y. Takebayashi and H. Mitani: Met. Trans., 12A (1981), 435.

24) H. Nagai and M. Okabayashi: Trans. JIM., 22 (1981) 101.

25) H. Nagai, F, Koshi-ishi, S, Ishikawa and K. Shoji: Trans. JIM., 24 (1983), 839.

26）永井, 興石, 岡田, 生司：沿体括よび粉末治金, 32 (1985), 14.

27）永井, 森下, 三木, 生司：粉体执よび粉末炲金, 32 (1985), 318.

28）永井，㵏山，庄司：粉体和上び粉末冶金，34 (1987)，22.

29) H. Nagai, T. Fujikawa and K. Shoji: Trans. JIM., 24 (1983), 581.

30) K. Hauffe and J. Block: Z. Phys. Chem., 198 (1961), 232.
31) W. A. Fischer and G. Lorenz: Arch. Eisenhüttenw., 28 (1957), 497.

32) K. A. Hay, F. G. Hicks and D. R. Holmes: Werkst. Korros., 21 (1970), 917.

33) W. C. Hagel and A. U. Seybolt: J. Electrochem. Soc., 108 (1961), 1146.

34) J. A. Crawford and R. W. Vest: J. Appl. Phys., 35 (1964), 2413.

35) P. Kofstad: Nonstoichiometry, Diffusion, and Electrical Conductivity in Binary Metal Oxides. Wiley-Interscience, N.Y. (1972), p. 204.

36) H. Nagai, S. Ishikawa, N. Amano and K. Shoji: Trans. JIM., 26 (1985), 753.

37) C. Wagner: J. Phys. Chem. Solid; 33 (1972), 1051. 